\title{
Magia e Ilusão: a face de Janus da técnica na reflexão de Walter Benjamin
}

\author{
José Edmar Lima Filho e \\ Tereza Callado ${ }^{1}$
}

\section{RESUMO}

$\mathrm{Na}$ avaliação crítica de Walter Benjamin a técnica registra a força de uma ambivalência, pois, se por um lado, interfere positivamente na autonomia do homem, também o sujeita, em tempos de crise, a estratégias de manipulação ideológica. No caso do cinema, a máquina emancipa a arte, na medida em que substitui seu valor de culto pelo de exposição necessário à educação das massas. Mas é à ameaça do efeito destrutivo da tecnologia, na guerra - que a imagem dialética de Benjamin reage com as ciências do homem, da antropologia à metafísica, da política à moral e até a arte, para impedir que o presente seja desfigurado com os traços hipocráticos da história

Palavras-chave: técnica, experiência, narrativa, justiça, Benjamin, memória

\section{ABSTRACT \\ Magic and illusion: the Janus face of the technique through the view of Benjamin}

The technique, through the critical evaluation of Walter Benjamin, records the force of an ambiguity. On one hand, it interferes positively in the autonomy of man, but it also forces him, in times of crisis, to strategies of ideological domination. In the case of cinema, the machine liberates art, as it replaces its cult value of the exhibition - necessary for the education of the masses. But is the threat of theirs destructive effect in war that the dialectical image in Benjamin reacts with science, from anthropology to metaphysics, from politics to morality and even to art, to prevent the present to be marred with Hippocrates traces of history.

Key-words: technique, experience, justice, memory, Benjamin

\section{Magia e Ilusão: a face de Janus da técnica na reflexão de Walter Benjamin}

Na tese 1 Sobre o Conceito de História (Über den Begriff der Geschichte) Walter Benjamin descreve a realidade do materialismo histórico vivenciado pelo mundo atual, com a alegoria de um jogador de xadrez. Trata-se de um mecanismo construído de espelhos dando-nos a experimentar ao mesmo tempo a magia e a descoberta de nossa ilusão, pois nos faz ver por trás da aparência de vencedor do boneco mecânico, os lances certeiros da teologia, que pequena e feia, não ousa mostrar-se. Escondida sob a mesa, ela aciona os cordões do materialismo (o boneco) ganhando todas as partidas. Por essa metáfora somos levados a crer

\footnotetext{
${ }^{1}$ José Edmar Lima Filho é Mestrando em Ética Fundamental do Curso de Mestrado Acadêmico em Filosofia da Universidade Estadual do Ceará - CMAF/UECE, sob a orientação do Prof. Dr. José Expedito Passos Lima. Bolsista da FUNCAP. E-mail: semedmar@ yahoo.com.br. Tereza Callado é Doutora em Filosofia pela Universidade de São Paulo (USP), com a tese Itinerário da Moral e a Lógica Política do Estado de Exceção em Walter Benjamin (2005). Doutora em Literatura pela Universidade de São Paulo (USP) com a tese Perspectivas da Alegorização em "Memórias Póstumas de Brás Cubas", em 1997. Com Pós-Graduação em Munique-Alemanha. Professora aposentada da UFC, atualmente é Professora de Filosofia do Mestrado Acadêmico em Filosofia da UECE, líder do grupo de pesquisa Walter Benjamin e a Filosofia Contemporânea e Editora, desde 2008, de Cadernos Walter Benjamin acessível no site http://www.gewebe.com.br/cadernos.htm.
} 
que nosso tempo é orientado pelo materialismo - pelo menos é o que se depreende da aparência do apetrecho - quando de repente a solidez de seu pragmatismo é desmistificada. $\mathrm{Na}$ ótica benjaminiana o materialismo histórico não deixa de ser amparado pela teologia - a verdadeira ganhadora. A ilusão do desempenho exclusivo do materialismo deve-se à técnica que, não obstante hoje disponha de muitos e gigantescos meios, paradoxalmente possui uma débil capacidade de esclarecer questões morais, ainda que na sociedade burguesa esteja extremamente ligada a um certo prestígio que lhe é atribuído pelo progresso (Fortschritt). Ele, na medida em que aponta para a dimensão da hegemonia que leva tudo, pela ideologia, à uniformização, solapa a criatividade e o valor da diferença. Quando o autor comenta a importância de se salvarem os fragmentos da tradição, na realidade está afirmando a unidade do singular, exemplificado na figura do mosaico medieval. Construído de pedaços, o mosaico agrega cada singularidade a outra para construir, na totalidade, a beleza do todo plástico. Benjamin se espelha nessa imagem para moldar uma nova teoria do conhecimento (Erkenntnistheorie) que privilegie o particular. A dimensão da transmissão da verdade contida na singularidade de cada um, concebido como mônada, é recepcionada pela frágil força messiânica derivada de um poder divino concedido ao homem. Ela se manifesta em forma de boa vontade e presença de espírito (Geistesgegenwart) e se transmite de geração a geração, enriquecendo o patrimônio cultural de experiência (Erfahrung) e dando sentido à arte da narrativa - receptáculo dos bens da humanidade engendrados pelo inconsciente coletivo. Entretanto, negando toda essa sabedoria, a volta silente dos soldados, depois da Guerra de 1914 - guerra técnica e de materiais -, mostra que não há mais o que ser dito. A riqueza do passado consistia em um conhecimento acumulado na tradição e expresso sob a forma de uma máxima recebida com veneração. Tratava-se da sabedoria. Mas nosso tempo parece rejeitar o conselho justamente porque carecemos de memória. Nesse ponto Benjamin alerta para a necessidade de se recuperar, da tradição, os signos disperso. O declínio paulatino da arte de narrar, com o avanço exorbitante da técnica, pôs em xeque a narrativa e com ela a condição de conciliar a memória à esperança para manter incólume a faculdade mimética junto à destinação humana. Os textos Sobre o Conceito de História de 1940, Experiência e Pobreza (Erfahrung und Armut) de 1933 e O Narrador (der Erzähler) de 1936 defenderão um método para lidar com a técnica, enquanto interface científica de um conhecimento absolutizado pela racionalidade iluminista.

Como é costume, a filosofia sempre se põe na esteira de seu tempo. Isso não significa dizer que sempre há uma consonância entre o momento histórico e a concepção filosófica dos autores. Por vezes é notória uma discrepância entre os fatos vividos e o posicionamento filosófico, pois em muitos casos este dito posicionamento filosófico é visionário, como acontece em Benjamin. Como filho da passagem do século IX ao XX, ele observa a realidade da barbárie cultural que circunscreve o seu tempo e a partir desse diagnóstico pretende avaliar o papel da filosofia resguardando a possibilidade de uma codificação da história, em que $o$ more gemetrico seja repensado com vistas a uma destinação humana. Para tanto, o mergulho na tradição se faz numa perspectiva de salvação (Erlösung) em que metáforas vazias tais liberdade, humanismo e sacralidade sejam desmistificadas para dar espaço à verdadeira reflexão político-teológica, pois a história contém em si ambivalências que, de per si, justificam a existência de fragmentos aparentemente contraditórios. $\mathrm{Na}$ verdade esses fenômenos dispersos precisam ser nomeados pelas ideias na medida em que elas, evitando que se autodispersem na indefinição, também sejam reconhecidas nos fenômenos. Um desses exemplos se encontra no comportamento ex-officio do estadista barroco, quando transgredindo o conceito de soberania do absolutismo - caracterizado pela tirania - deixa que se revele a sua singularidade na forma de conduzir o reino à salvação. Essa atitude marca a hegemonia cristã incontestada do barroco, caracteriza-se na prática da compaixão (Mitleid), quando, para reinar com justiça, o príncipe a interioriza em favor do outro, com a repressão 
dos afetos na alma ou sua mobilização em direção a outros afetos. Tal sintonia se estabelece no olhar sobre a condição de mortal do súdito, em que o governante reconhece, no lance de uma iluminação profana ( profane Erleuchtung) do pensamento, a verdade de sua própria miséria. Esse dado da soberania do século XVII visualizado no conteúdo de verdade (Wahrheitsgehalt) da arte é, no entanto, desconhecido e por isso negligenciado pelos manuais de História da Filosofia que descrevem, exclusivamente sob a óptica absolutista da tirania o sistema jurídico do principado barroco cuja prescrição para o soberano consistia na função sacrossanta dada por Deus, ditada pelo Direito Constitucional em vigor.

Nesse sentido é que aparece, na filosofia benjaminiana, a importância de se salvaguardar a diferença isolada por um universal extraído da média. Com a visualização do mosaico medieval, em que cada fragmento possui importância fundamental na composição da totalidade, Benjamin observa, na obra-de-arte (Kunstwerk) uma maneira diferente de enfrentar a lógica da ciência em que a ordem das coisas, segundo Espinosa, seria a mesma que a das ideias. $^{2}$ Benjamin cita Goethe para justificar a lógica da percepção artística que infringe uma ordem para as coisas na constelação das ideias: "não devemos procurar "a totalidade no universal, no excessivo, pois assim como a arte se manifesta sempre, como um todo, em cada obra individual, assim a ciência deveria manifestar-se sempre, em cada objeto estudado". ${ }^{3} \mathrm{~A}$ mesma busca pela verdade do singular se dá no plano lógico, quando a metodologia benjaminiana do caminho indireto (Umwege) e do desvio se espelha no método do tratado, que diz respeito aos objetos da teologia, sem os quais não se pode conceber a verdade (Wahrheit). A quintessência do tratado é a representação (Darstellung), a verdadeira forma da investigação filosófica. Nessa lógica, à medida que a reflexão renuncia a uma intenção, na contemplação ao alvo de investigação - Deus - o pensamento retorna sempre de novo, em um fôlego infatigável. E a contemplação, ao retornar ao mesmo objeto investigando os diversos planos de seu sentido, vai buscar um novo estímulo para um recomeço perpétuo e uma justificação para a intermitência do seu ritmo. ${ }^{4}$ Dessa forma se veem salvos todos os extratos da significação, como camadas superpostas de um palimpsesto revelado, pois Benjamin percebe a urgência de se redimir o particular frente à metodologia cartesiana dedutiva, onde o fenômeno desaparece e onde as ideias são reduzidas a uma mera definição, impossibilitadas, pela cadeia de razões (catena), a recolher o transitório e o fragmentário. Nos métodos dedutivo e indutivo da ciência que se processam sem lacunas, o efêmero e o mutável se perdem. Com o fim de recuperá-los para o pensamento, Benjamin reage com "a configuração de ideias" em que um extremo se encontra com outro extremo. ${ }^{5} \mathrm{Se}$ o método indutivo se abstém de classificar e ordenar as ideias, o método dedutivo as coloca em um continuum pseudológico. O resultado é que ambas as tentativas de sistematização degradam as ideias em conceitos (die Ideen zu Begriffen herabwürdigen), ${ }^{6}$ onde o particular é subsumido em nome de um universal, extraído da média. Esse método cartesiano dos Regulae ad directionem Ingenii postula a totalidade como um dado e comporta-se como se dispusesse de um todo indiferente ao acaso, ao imprevisível e à contingência. $\mathrm{Na}$ dimensão da técnica construída sobre a razão instrumentalizada, esses elementos ora abandonados, reaparecem, em sua forma espectral, retornam como mecanismos mágicos e artifícios que não encontraram espaço no

\footnotetext{
${ }^{2}$ Epígrafe de Adorno sobre o ensaio in: Max Horkheimer. Teoria crítica. Tradução: Hilde Cohn, São Paulo: Perspectiva, 1990, p. XIII

${ }^{3}$ Johann Wolfgang von Goethe. Materialen zur Geschichte der Farbenlehre apud Walter Benjamin.

"Erkenntniskritische Vorrede" in: Ursprung des deutschen Trauerspiels, Frankfurt am Main: Suhrkamp, 1978, S. 9.

${ }^{4}$ Walter Benjamin. Origem do drama barroco alemão.Tradução: Sérgio Paulo Rouanet, São Paulo: Brasiliense, 1984 , p. 50.

${ }^{5}$ Walter Benjamin. Origem do drama barroco alemão. Opus cit. p. 57.

${ }^{6}$ Walter Benjamin. Origem do drama barroco alemão . Opus cit. p. 68-69. Ursprung des deutschen

Trauerspiels. S. 25.
} 
sistema da calculabilidade convocada pela ciência. No artefato da ordem cientificista toda individualidade e criatividade são substituídas pela homogeneidade e padronização. Uma das evidências do artifício que a técnica emprega quando ela se reapropria de outras articulações da psiquê humana ou seja, poesia e mística, encontra-se na concepção do camundongo Mickey citado em Experiência e Pobreza., como símbolo das proezas tecnológicas do nosso tempo. Sua habilidade incontestável, expressa em peripécias e soluções mágicas travadas pela origem tecnológica, leva adiante a realização mais plausível da "dimensão serial e processual" do milagre negado à esfera religiosa, pelo cientificismo, na tradição racionalista da consciência esclarecida. A reprodutibilidade da obra de arte é um exemplo cabal disto: pelo uso da técnica, falta a autenticidade, o hic et nunc do original, sua existência única, substituída pela massificação, nos mecanismos processuais de uniformização da cultura. Ora, este aqui e agora, enquanto conteúdo mesmo da autenticidade de uma dada obra de arte, contém em si toda uma tradição e, nela, uma dimensão de autoridade que já não existe mais:

A autenticidade de uma coisa é a quintessência de tudo o que foi transmitido pela tradição, a partir de sua origem, desde sua duração material até seu testemunho histórico. Como este depende da materialidade da obra, quando ela se esquiva do homem através da reprodução, também o testemunho se perde. Sem dúvida, só esse testemunho desaparece, mas o que desaparece com ele é a autoridade da coisa, seu peso tradicional ${ }^{7}$.

No Konvolut $\mathrm{N}$ da obra das passagens o filósofo nos faz ver a possibilidade de que "a continuidade da tradição seja uma aparência. Mas então é a permanência desta aparência de permanência que cria nela a continuidade". ${ }^{8}$ Em sendo assim, a aparência de "algo de muito vivo" da tradição é encarada a partir da possibilidade de nela se encontrarem fragmentos riquíssimos. Não existem épocas de decadência (Es gibt keine Verfallzeiten)" Por isso, "[...] nada do que um dia aconteceu pode ser considerado perdido para a história"", o que impossibilita pensar em épocas da história que não possam ser recuperadas pela memória (Eingedenken) do passado com seu apelo ao presente. Ora, se assim o é, "[...] existe um encontro secreto, marcado entre as gerações precedentes e a nossa" ${ }^{10}$, e isso acaba manifestando a importância de se refletir na semântica das coisas destruídas que, como se vê hoje, acaba se confundindo com os destroços da história. Aqui deve interferir a racionalidade na sua versão atual: a reflexão (Grübeln) acionada pelo choque, nas contingências da fantasmagoria da metrópole. Choque e despertar (Erwachen) são contraestratégias proporcionais à aceleração do progresso que não permite que nada se fixe. O agora da cognoscibilidade - em que todo o conhecimento da humanidade é conjugado em favor da razão humana - é o momento do despertar: "(Jung quer manter o despertar longe do sonho)". ${ }^{11}$ Benjamin compreende que se o sonho da civilização foi realizado pela técnica, trazendo com ela espectros para o cenário de fantasmagoria da metrópole, o despertar acontece com o conhecimento a serviço da destinação humana, a presença de espírito (Geistesgegenwart) enquanto uma categoria política, ${ }^{12}$ que atualiza a experiência da sabedoria, pois enquanto $a$

\footnotetext{
${ }^{7}$ Walter Benjamin. "A obra de arte na era de sua reprodutibilidade técnica" in: Walter Benjamin. Magia $e$ técnica, arte e política: ensaios sobre a literatura e a história da cultura. São Paulo: Brasiliense, 1994, p. 168.

${ }^{8}$ Walter Benjamin. Passagens. Opus cit. p. 528.

${ }^{9}$ Walter Benjamin. "Sobre o conceito de história" in: Walter Benjamin. Magia e técnica, arte e política: ensaios sobre a literatura e a história da cultura. São Paulo: Brasiliense, 1994, p. 223.

${ }^{10}$ Walter Benjamin. Sobre o conceito de história. Op. cit., p. 223.

${ }^{11}$ Walter Benjamin. "Fascículo N" in: Obra das Passagens (Trad. Willi Bolle et allii). Belo Horizonte: Humanitas, 2006, p. 528

${ }^{12}$ Walter Benjamin. "Fascículo N" in: Obra das Passagens, Opus cit, p. 520.
} 
experiência é o fruto do trabalho, a vivência é a fantasmagoria do ocioso. ${ }^{13}$ A experiência se faz no inconsciente, a vivência nos choques do cotidiano, nas pequenas fissuras entre a avalanche do progresso que impulsiona tudo para o futuro. Mas é preciso salvar o que está por vir de sua forma presente desfigurada ${ }^{14}$ resistindo à pressão da novidade da moda que nega $o$ novo no sempre igual (das Immergleiche) da mercadoria, iludindo acerca do bem-estar e da felicidade (Glück). O filósofo compreende que ela (a felicidade) não pode estar no acabado e no completo do sistema, ${ }^{15}$ que reprimem a atuação messiânica da criatura no mundo, bloqueando o pensamento em uma síntese concreta. Para reverter esse processo de redução do pensamento o filósofo observa que "a história antes de ser uma ciência é uma forma de reminiscência". Benjamin como Gerhard Scholem Benjamin é leitor da mística judaica. Nos ensinamentos dos hebreus observa que uma vez entregue por Deus aos homens o texto sagrado da lei divina - a Halacha - resta a este sua interpretação pela memória, na Hagada. ${ }^{16}$ Compreende-se um planejamento divino na tarefa de recriação dada ao homem, com base na explicação do fenômeno do Tzimtzum descrito por Isaac Luria. Alude este ao primeiro ato da criação como ato de revelação e de limitação, "em que Deus limita a si Mesmo": ${ }^{17}$

Conta a tradição do Midrasch, em algumas sentenças de mestres do século III que Deus concentrou sua Schehiná, sua presença divina, no Santo dos Santos, lá onde se acham os Querubins, embora todo o Seu poder estivesse concentrado e contraído num único ponto (...) Temos aqui a origem do termo Tzimtzum (...) Para os cabalistas da escola de Luria Tzimtzum não significa a concentração de Deus em um ponto, mas sua retirada de um ponto(...) Tzimtzum é o mais profundo símbolo do exílio ${ }^{18}$

Nessa interpretação de Luria o excesso de irradiação da luz divina fragmenta um imenso vaso, dando origem ao mundo. Simultaneamente Deus recua para dar espaço ao homem. ${ }^{19} \mathrm{~A}$ desordem aparece quando, aos elementos da ordem divina vieram misturar-se os viciosos, gerando o caos. Nesse momento fragmentos que ainda retinham algumas centelhas da irradiação do Pleroma emanaram para a restauração da ordem ideal que "constitui o objetivo original da criação, também é o propósito secreto de existência”:

Para Luria o aparecimento do Messias nada mais é que a consumação do processo contínuo da Restauração do Tikun. A verdadeira natureza da

\footnotetext{
${ }^{13}$ Walter Benjamin. "Fascículo M" in: Obra das Passagens. Opus cit. p. 840

${ }^{14}$ Walter Benjamin. "A Vida dos Estudantes" in: Documentos de Cultura documentos de barbárie (Org. e Trad. Willi Bolle), São Paulo: Cultrix: Editora da Universidade de São Paulo, 1986, p.151.

${ }^{15} \mathrm{O}$ que a ciência estabeleceu pode ser modificado pela rememoração. Esta pode transformar o inacabado ( a felicidade) em algo acabado, e o acabado (o sofrimento) em algo inacabado. Isto é teologia; Na rememoração fazemos uma experiência que nos proíbe de conceber a história como fundamentalmente ateológica, embora tampouco nos seja permitido tentar escrevê-la em conceitos imediatamente teológicos. Walter Benjamin. Fascículo N. Passagens. Opus cit. p. 513.

${ }^{16}$ J. Gagnebin. "Walter Benjamin ou a história aberta" - prefácio de Magia e Técnica Arte e Política. Opus cit. p. 17

${ }_{17}^{17}$ G. Scholem. Mística Judaica (Trad. Dora Ruhman), São Paulo: Perspectiva, 1972, p. 266.

18 "A existência do universo é possível devido ao processo de contração em Deus". De acordo com Luria Deus foi compelido a dar espaço ao mundo, abandonando, por assim dizer, uma região dentro Dele, uma espécie de espaço primordial místico de onde Ele se retirou a fim de voltar aí no ato da Criação e Revelação”. (...) em nota 44 de rodapé Scholem continua: "as imagens apresentadas nessa conexão em algumas versões manuscritas da doutrina de Vital distinguem-se por sua colaboração altamente naturalista, se não materialista”. G. Scholem.

Mística Judaica. Opus cit. p. 263-264

${ }^{19}$ G. Scholem. Idem. p. 263
} 
redenção é portanto mística e seus aspectos históricos e nacionais são meros sintomas auxiliares que constituem um símbolo visível de sua consumação (...) o mundo do Tikun é o mundo da ação messiânica. ${ }^{20}$

Tikun, para usar um termo hebraico é a reintegração, constituindo para Benjamin a motivação para a criação do conceito restitutio in integrum do fragmento teológico-político. Nessa ótica da criação cabe a cada homem a coparticipação no projeto de reconstrução, ou seja restaurar as luzes espalhadas de Deus em seu lugar certo. Mas ao mesmo tempo esse Deus absconditus pascalino, ou seja Ein-Sof oculto, a substância impessoal ${ }^{21}$ deixa entrever a história como marcha dos degredados, de injustiçados e oprimidos, aguardando do homem a ação de restauração do conjunto original: "agora que os vasos estão quebrados, um novo fluxo de luz mana da fonte original do Ein-sof(...) e imprime uma outra direção aos elementos desordenados". Essa transição exclui a tentativa de construção de uma racionalidade distanta da concepção de Deus vivo como macro-anthropos". ${ }^{22}$ As desproporções históricas e os excessos tais como Auschwitz provaram que não existe uma racionalidade positivistakantiano-hegeliana-idealista que projeta a história para um desenvolvimento incondicional e incondicionalmente progressivo. Por isso é importante dar um fim a história oficial - aquela que escreve a história dos vencedores (Herrschenden) e não dos vencidos (Unterdrückten) e que faz de cada monumento de cultura um monumento de barbárie. ${ }^{23}$ Benjamin traça o caminho de uma restauração com o apelo à frágil força messiânica que emana da irradiação da luz divina dispersa pelo mundo. Portanto o modelo da história oficial deve ser destruído para se reinaugurar uma nova face da história, contra aquela facies hippocratica, como protopaisagem petrificada de que trata o Ursprung des deutschen Trauerspiels, no comentário sobre a perda do ethos histórico. ${ }^{24}$ A mesma rigidez Benjamin observa na matéria inorgânica da mercadoria. Contra esse status quo, a tentativa de alerta, de afirmação, de resistência pela subversão de conceitos, se faz na construção de uma teoria do conhecimento que privilegie o lugar do singular contra a ideia de um sujeito do conhecimento, que só se realiza para Benjamin na ironia. O filósofo reconhece na estruturação desse sujeito as mesmas forças míticas instituintes e mantenedoras do sistema jurídico como princípio abissal de abstração entre o condicionamento da culpa à expiação, que é desarticulado pelo poder divino da educar através da existência. Preencher todo o espaço que a ideologia considera esvaziado de sentido é uma realização que alcança seu paroxismo nos extratos do princípio abstracionista do mercado cuja função é passar a ideia de uma felicidade, de uma pseudo felicidade, diga-se, onde se diluem cada vez mais os anseios reais e anímicos da vida. Portanto é preciso reconhecer a fraude do progresso escovando a história a contrapelo (die Geschichte gegen den Strich zu bürsten), ${ }^{25}$ para observar o que a tradição esconde e atualizála no Bem.

A transmissão da verdade é um fato que se dá por meio da experiência (Erfahrung), que se esgota junto à tradição, pois técnica quer reinar soberana, excluindo os elementos místicos da articulação psíquica humana, para apoderar-se deles a serviço do próprio lucro. Portanto embota a possibilidade de transmissão da verdade, na medida em que, por meio da reprodução, "[...] destaca, do domínio da tradição, o objeto reproduzido", ${ }^{26}$ transformando-o de objeto de culto (Kultwert) a objeto de exposição (Ausstellungswert), na medida em que destruindo sua aura, substitui a existência única do original por uma existência serial, num

\footnotetext{
${ }^{20}$ G. Scholem. Idem. p. 271

${ }^{21}$ G. Scholem. Idem. p. 274

${ }^{22}$ G. Scholem. Idem. P. 272

${ }^{23}$ Walter Benjamin. "Sobre o Conceito de História". Opus cit. p. 225

${ }^{24}$ Walter Benjamin. Origem do drama barroco alemão. Opus cit. p. 188

${ }^{25}$ Walter Benjamin. "Sobre o Conceito de História". Opus cit. p. 225.

${ }^{26}$ Walter Benjamin. A obra de arte na era de sua reprodutibilidade técnica. Op. cit., p. 168.
} 
processo sintomático que impede a experiência, enquanto comunicabilidade de vivência política:

\begin{abstract}
A experiência é o que nos passa, o que nos acontece, o que nos toca. Não o que se passa, não o que acontece, ou o que toca. A cada dia se passam muitas coisas porém, ao mesmo tempo, quase nada acontece. Dir-se-ia que tudo o que passa está organizado para que nada nos aconteça ${ }^{27}$.
\end{abstract}

O automatismo incrementado pela técnica impede a utilização da faculdade mimética e dos sentidos onto e filogenético. No exercício pleno dessa mimese o homem se reconhecia parte da physis, na concepção dos antigos, vivendo em celebração e contemplação dos corpos celestes, em harmonia com o mundo: pedras e águas dos oceanos, quando toda a natureza conspirava a seu favor. A possibilidade de um retorno (restitutio) na suspensão do tempo de opressão para instaurar esse estado de alma paradisíaco estaria na concretização do pensamento, pela inteligência, estimulada a despertar, quando concentrada no agora (Jetztzeit) de origem messiânica. A ação para a plenitude de um tempo salvífico, no combate à fantasmagoria da vida atual, se daria em um esforço em direção à sabedoria acumulada pela civilização e esquecida no fundo de um fosso junto aos dejetos que já não circulam como objetos de lucro, foram ultrapassados, pois o princípio do mercado é de outra ordem: troca pela moeda miúda do atual o patrimônio da civilização: a amizade, as relações de coração, coragem, humor e amor jazem, enxovalhados a um canto, como despojos ganhos pelos vencedores (Sieger). Lamenta-se que esse patrimônio não se vincule mais a nós pela experiência, no processo de transmissão da sabedoria, através da competência que estrutura a verdadeira autoridade. Sua falência adveio do nascimento do autoritarismo, nas incursões aos veículos de comunicação manipulados pela mídia e tratados com a retórica da informação que seduz com o objetivo de dominar: Phrase é a palavra dada por Benjamin à técnica da linguagem jornalística, da retórica persuasiva debulhada do seu peso semântico. O que se percebe é que hoje, pelo desenvolvimento constante da técnica ${ }^{28}$ que se sobrepõe ao homem, há uma baixa de experiências dando surgimento a novas formas de miséria. Assim, nosso tempo comporta uma grande contradição: a riqueza de ideias que se impõe ao homem atual não é compatível com a transmissibilidade de experiências ${ }^{29}$. Esse fenômeno impõe a vertigem como condição de um universo espiritual rasgado pelo domínio das contradições ${ }^{30}$ em que Benjamin reconhece a pós-história do barroco. Por esse motivo, no opúsculo Experiência e Pobreza, faz-se referência ao período da Primeira Grande Guerra Mundial (1914-1918), “[...] uma das mais terríveis experiências da história”31 , quando os soldados, ao regressarem do campo de batalha, "voltaram silentes":

\footnotetext{
${ }^{27}$ J. Larrosa. Notas sobre a experiência e o saber de experiência. Palestra proferida no $13^{\circ}$ COLE-Congresso de Leitura do Brasil, Unicamp, Campinas/SP, julho de $2001 . \quad<$ http:// www.miniweb.com.br/Atualidade/INFO/textos/saber.htm>. Acesso em junho de 2005. In: BESSA, B. S. As experiências de Walter Benjamin. Morpheus - Revista Eletrônica em Ciências Humanas - Ano 05, número 09, 2006 - ISSN 1676-2924. Disponível em http://www.unirio.br/morpheusonline/numero09-2006/bessa.htm\#_edn1. Acesso em 12 de março de 2010.

28 “. [...] na medida em que [...] [a] técnica permite à reprodução vir ao encontro do espectador, em todas as situações, ela atualiza o objeto reproduzido. Esses dois processos resultam num violento abalo da tradição, que constitui o reverso da crise atual e a renovação da humanidade. Eles se relacionam intimamente com os movimentos de massa, em nossos dias" Walter Benjamin. A obra de arte na era de sua reprodutibilidade técnica. Op. cit., p. 169).

29 "[...] qual o valor de todo o nosso patrimônio cultural, se a experiência não mais o vincula a nós?" Walter Benjamin. Experiência e pobreza. in: Walter Benjamin. Magia e técnica, arte e política: ensaios sobre a literatura e a história da cultura. São Paulo: Brasiliense, 1994, p. 115.

${ }^{30}$ Walter Benjamin. Origem do drama barroco alemão. Opus cit. p. 79.

${ }^{31}$ Walter Benjamin. Experiência e pobreza. Op. cit., p. 114.
} 
Uma geração que ainda fora à escola num bonde puxado por cavalos viuse abandonada, sem teto, numa paisagem diferente de tudo, exceto nas nuvens, e em cujo centro, num campo de forças de correntes e explosões destruidoras, estava o frágil e minúsculo corpo humano ${ }^{32}$.

O resultado do desenvolvimento da técnica não foi tão positivo assim para o ser humano. Na verdade, foi absolutamente negativo quando o que se percebe é que, em nossos tempos, ela sobrepuja o homem e faz surgir uma nova forma de miséria, o que parece se contrapor à enorme riqueza de ideias - herança de um falso humanismo, em uma tradição fáustica - que se conhece e se impõe ao indivíduo de hoje ${ }^{33}$, como se o homem vendesse sua alma ao diabo à maneira de Fausto. Goethe nos dá, com essa alegoria, a medida certa da grandiloquência da palavra progresso (Fortschritt): depois que Mefistófeles, induzindo Fausto a concordar com a repartição equitativa da terra entre os camponeses, retorna para prestar-lhe conta a seu modo e feitio, não se constrange em apregoar cinicamente que teve de sacrificar um casal de velhos que resistiam, ateando fogo à sua casa, para que pudesse dispor livremente da área para o loteamento do latifúndio. O mito prova que o projeto da racionalidade das luzes excluiu aqueles elementos anímicos que estavam na base das relações de afetividade, solidariedade e respeito entre as pessoas, equilibrando a vida na comunidade. Esse conto nos dá a medida do expatriamento do "sujeito" e das condições impostas a ele em troca de sua "liberdade".

A consequência dessa vinculação entre novas ideias ou ideias grandiloquentes da consciência esclarecida e o indivíduo se dá na geração de uma nova barbárie ${ }^{34}$, percebida na honrosa confissão da pobreza individual, pobreza de experiência. Ela interfere diretamente na vida orgânica da criatura, transformando o espaço do corpo (Leibraum) em mera vida (blosses Leben) onde o homem de outrora se vê reduzido a um autômato, pelos mecanismos da técnica dominada por um poder mítico: é o que nós podemos deduzir da leitura do manifesto de Marinetti, afirmando que: "há vinte anos, nós, futuristas contestamos a afirmação de que a guerra é antiestética... por isso dizemos:

a guerra é bela porque graças às máscaras de gás, aos megafones assustadores. Aos lança-chamas e aos tanques, funda a supremacia do homem sobre a máquina subjugada.. A guerra é bela porque inaugura a metalização onírica do corpo humano. A guerra é bela porque enriquece um prado florido com as orquídeas de fogo das metralhadoras. A guerra é bela, porque conjuga numa sinfonia os tiros de fuzil, os canhoneios, as pausas entre duas batalhas, os perfumes e os odores de decomposição",35

\footnotetext{
${ }^{32}$ Walter Benjamin. Experiência e pobreza. Op. cit. p. 115. Vale salientar que para Benjamin a guerra apresenta traços místicos e forças mágicas que lhe estão subjacentes, criticando uma certa apologia da guerra forjada por alguns autores, tentando apontar neles a defesa de um certo heroísmo decorrente do uso bélico da técnica, por ele criticado por representarem traços de morte: "Com lança-chamas e trincheiras, a técnica tentou realçar os traços heróicos no rosto do idealismo alemão. Foi um equívoco. Porque os traços que ela julgava serem heróicos eram na verdade traços hipocráticos, os traços da morte. Por isso, profundamente impregnada por sua própria perversidade, a técnica modelou o rosto apocalíptico da natureza e reduziu-a ao silêncio [...]" Walter Benjamin. Teorias do fascismo alemão. in: Magia e técnica, arte e política: ensaios sobre a literatura e a história da cultura. São Paulo: Brasiliense, 1994, p. 70

33 “"...] [há uma] distância abissal entre os meios gigantescos de que dispõe a técnica, por um lado, e sua débil capacidade de esclarecer questões morais, por outro" Walter Benjamin. Teorias do fascismo alemão. Op. cit., p. 61.

34 "Qual o valor de todo o nosso patrimônio cultural, se a experiência não mais o vincula a nós?" Walter Benjamin. Experiência e pobreza. Op. cit. p. 115.

${ }^{35}$ Walter Benjamin. Opus cit. p. 195-196.
} 
É preciso, pois, com base na constatação da pobreza do bárbaro, empreender um novo caminho, um novo princípio, contentando-nos com pouco e olhando para frente. Essa proposta sintoniza com o caráter destrutivo, que não exige nada além de espaço e ar puro, pois para ele, a qualquer momento tudo pode andar mal. A experiência com a vida o previne para os dias que virão. Por isso ele anda sempre de bom humor:

O caráter destrutivo é o adversário do homem estojo. O homem estojo busca sua comodidade, e sua caixa é a síntese desta. O interior da caixa é o rastro revestido de veludo que ele imprimiu no mundo. $\mathrm{O}$ caráter destrutivo elimina até mesmo os vestígios da destruição(...) O caráter destrutivo tem a consciência do homem histórico(...) o caráter destrutivo não vê nada de duradouro. Mas eis precisamente por que vê caminhos por toda parte. Onde outros esbarram em muros ou montanhas, também aí ele vê um caminho(...) Já que vê caminhos por toda parte está sempre na encruzilhada. Nenhum momento é capaz de saber o que o próximo traz. O que existe ele converte em ruínas, não por causa das ruínas, mas por causa do caminho que passa a través delas. ${ }^{36}$

A figura do caráter destrutivo é construída sobre a transgressão aos parâmetros culturais por encontrar neles a sistematização viciada da norma. A compatibilidade com "O homem sem qualidades der Mann ohne Eigenschaften" de Robert Musil, publicado em 1933, se dá na desqualificação da norma como instância crítica, ${ }^{37}$ assumindo a instabilidade da padronização imposta pela cultura transformada em barbárie que se distancia cada vez mais dos anseios daquela realização anímica e da expressão da espontaneidade.

Com a imagem do caráter destrutivo Benjamin constrói uma dialética na imobilidade (Dialektik im Stillstand), ou seja, uma metodologia mimética da cultura para desarticular o vício de destruição imposto pela máquina em um mundo que perdeu sua capacidade de sintetizar e onde se abrem por toda parte abismos entre o ser e a existência, que a ideologia, mascarada de progresso, pretende preencher a sua maneira. Não há mais como deixar de ver, nas manifestações da cultura, a ironia que se esconde no particular reagindo ao cinismo de um mundo que perdeu sua aura e seu caráter de sacralidade e que tenta a todo custo retomá-la na sua feição mítica regurgitada pela técnica. A despeito de uma face positiva que Benjamin visualiza na técnica, na medida em que se possa fazer dela um prolongamento dos órgãos do próprio corpo, o lado obscuro denunciado não poupa o tom indignado com que descreve as perversões cometidas pela técnica quando submetida a mãos inescrupulosas. Benjamin fala do condicionamento técnico do fenômeno aurático no texto sobre a fotografia. $\mathrm{O}$ mesmo se aplica ao aparato de sedução acionado para as instâncias de guerra, quando afirma que "a técnica não é suficientemente forte para dominar as forças elementares da sociedade". ${ }^{38}$ Quais seriam essas forças? Podemos nomeá-las com facilidade. Elas se encontram nos gigantescos meios de utilização da técnica para fins de lucro, de dominação, de segregação, e de extermínio. O que provoca a nossa perplexidade ao ler o ensaio é o fato de se saber que Benjamin ainda não tinha sido informado dos horrores das câmaras de gás que seriam utilizadas mais tarde nos campos de concentração (Lager) nazistas. Mesmo assim o tom premonitório de seu artigo Teorias do fascismo alemão, com uma crítica acirrada sobre a coletânea Guerra e guerreiros, editada por Ernst Jünger, desabafa o terror diante da imagem

\footnotetext{
${ }^{36}$ Walter Benjamin "O caráter destrutivo - Imagens do Pensamento" in: Rua de Mão única-Obras Escolhidas II, Tradução: Rubens Rodrigues Torres Filho e José Carlos Martins Barbosa, São Paulo: Brasiliense, 1987, p. 237.

${ }^{37}$ Walter Benjamin. Origem do drama barroco alemão. Opus cit. p. 67

${ }^{38}$ Walter Benjamin. Teorias do Fascismo Alemão. Opus cit. p. 61.
} 
do que poderia acontecer à sociedade de seu tempo, caso uma massa de recursos tecnológicos alcançasse o interesse de criminosos. $\mathrm{O}$ tom fatídico dessa advertência nos alarma mais ainda não só pelos horrores do holocausto, mas por sabê-lo erigido sobre as inócuas propostas de um idealismo sensabor cogitado nos fumos da abstração. Benjamin o comenta com toda amargura:

Os gênios da paz que habitavam (a paisagem) tão sensoriamente, foram evacuados, e tão longe quanto nosso olhar podia ir além dos cemitérios, toda a região circundante tinha se transformado em terreno do idealismo alemão, cada cratera produzida pela explosão de uma granada se convertera num problema, cada emaranhado de arame construído para deter a progressão do inimigo se convertera numa antinomia, cada farpa de ferro se convertera numa definição, cada explosão se convertera numa tese, com o céu, durante o dia, representando o forro cósmico do capacete de aço e, de noite, a lei moral sobre nós. ${ }^{39}$

O ensaio deixa entrever a necessidade de uma vigilância reflexiva constante traduzida com a urgência da ação política inspirada pelo despertar (Erwachen) do inconsciente e de seu salto para a superfície da consciência histórica. A teoria do conhecimento benjaminana reage à fragilidade do elemento conceitual em dizer o real, quando da assinatura daqueles elementos cognitivos objetificantes assimilados no dossiê do projeto positivista. O conceito pertence ao circuito da linguagem em exílio de seu "direito de nomeação", em que sua dispersão comunicacional a vitimou à deliquescência e a deriva do sentido na abstração das terminologias - "tentativas mal sucedidas de nomeação em que a intenção tem um peso maior do que a linguagem". ${ }^{40}$ Para Benjamin a linguagem perdeu a força para dizer as ideias "de forma não intencional, no ato nomeador" e o poder da "objetividade que a história conferiu às principais correntes da reflexão filosófica" ${ }^{41} \mathrm{O}$ conceito é apenas mediação entre ideia e fenômeno, não significa que ele se libertará tão facilmente de seu invólucro construído pela convenção, pelo código derivado de uma mera retórica. Esse fato já tinha ocupado a querela platônica em Górgias e Crátilo, quanto à justeza do nome e a persuasão do "belo" exórdio sofístico, na ocasião em que Platão quer salvar o discurso da verdade. Para Benjamin não existe ideia sem empiria. Só essa relação pode transformar a dinâmica histórica em ação política com seu fundamento teológico, onde no projeto estético de salvação "só Eros pode testemunhar que a verdade não é desnudamento que aniquila o segredo, mas revelação que lhe faz justiça". ${ }^{42}$ Portanto o expatriamento do Belo e da Verdade em um mundo que se dilui na orgia do estetismo condicionam o mundo à magia fraudulenta da técnica que simula uma beleza na palidez cadavérica das figuras do Jugendstil da passagem do século, retrato de uma realidade mascarada que exibe a mercadoria como coisa morta, único objeto capaz de ser produzido pela técnica a serviço do interesse do lucro e da feição estereotipada que a existência assumiu na exteriorização ostensiva do conhecimento. Por isso é no clima enlutado que a meditação sobre a existência se dá: "o luto é o estado de espírito em que o sentimento reanima o mundo vazio, ob a forma de uma máscara, para receber da visão desse mundo uma compensação enigmática. Cada sentimento está vinculado a um objeto apriorístico, e a representação desse objeto é a sua fenomenologia. ${ }^{" 43} \mathrm{~A}$ magia da mercadoria não consegue desanuviar essa sensação de luto que só por um instante fugaz pode ser alienada, pois "os sentimentos por mais vagos que eles pareçam na ótica da autopercepção (do melancólico) reagem, como num reflexo motor, à constituição objetiva do mundo". As leis do nosso mundo baseadas no princípio da excelência mercadológica se espelham nas leis da representação do barroco. Ambas estão vinculadas à plenitude de um objeto. No barroco o supremo adereço cênico (Requisit) é o objeto sobre o qual circulam todos os sentimentos e em torno do qual as emoções se fecham. Os objetos possuem um poder superior ao homem. É o punhal que fere e não a mão criminosa. É o travesseiro que sufoca Desdemona em Otelo de Shakespeare e não o marido enciumado, inflamado por Iago.

\footnotetext{
${ }^{39}$ Walter Benjamin. Teorias do Fascismo Alemão. Opus cit. p. 69-70.

${ }^{40}$ Walter Benjamin. Origem do drama barroco alemão. Opus cit. p. 59.

${ }^{41}$ Walter Benjamin. Idem, p. 59.

${ }^{42}$ Walter Benjamin. Idem. p. 53.

${ }^{43}$ Walter Benjamin. Idem. P.162
} 
Há quem, por absoluta desilusão com este século e por fidelidade estrita a ele, já tem começado a se ajustar a um novo estágio, utilizando uma nova linguagem "desumanizada", ao mesmo tempo uma linguagem da "gente" - contrapondo-se ao ideal humanista renascentista da compreensão antropocêntrica do mundo -, e hospedando essa "gente" em casas de vidro, onde não há possibilidade de se deixarem rastros. Felizmente essas casas de vidro são capazes de devassar o Ego, denunciar seus elementos narcísicos para recuperar o verdadeiramente humano. Tudo isso é decorrência daquilo que Benjamin chama de "pobreza de experiência". Uma experiência desse tipo deve ser repudiada, pois se fundamenta num ideal antropológico de "[...] uma existência que se basta a si mesma"44, que gerou o individualismo e o pragmatismo do mundo atual, contra o qual atua a função desantropomorfizadora da alegoria, como armadura da modernidade. ${ }^{45}$

Nossa pobreza é apresentada pelo autor a partir do momento em que percebe o abandono, de nossa parte, de cada peça do patrimônio humano, trocado pela atual riqueza de ideias desligadas de nós ${ }^{46}$. É desta crise de experiência que se segue a crise da narrativa, receptáculo que abriga os resíduos históricos que foram forjados pelo inconsciente coletivo ${ }^{47}$. E isso porque a narrativa é como que uma arte, mas que está em vias de extinção, dado que pressupõe a experiência como sua condição de possibilidade; noutros termos: nossa "[...] faculdade de intercambiar experiências". 48

O narrador, entretanto, pode realizar a sua arte de narrar a partir de dois modelos, a saber, o do camponês sedentário e o do marujo migrante, cujo labor evidencia a extensão do reino narrativo. Nesse circuito podemos observar um retorno àquelas formas arcaicas de lidar com a terra que já se encontra nos poemas de Hesíodo e Homero. A batalha com os elementos da natureza, no trabalho árduo com o solo pedregoso, no enfrentamento de sua causticidade e aspereza, numa relação de troca e doação, para poder extrair dela a subsistência, não deixa de mostrar o seu aspecto construtivo e solidário e expor a capacidade de integração com o macro-cosmo, e a harmonia do conceito clássico de physis, de que a consciência atual se abstém. Outro aspecto observado por Benjamin na narrativa é seu caráter artesanal, afetivo, laboral e criativo que desafia a natureza fabril do objeto no processo produtivo (Herstellungsverfahren).

Por viverem experiências fundamentais, estas figuras: a do camponês e do marinheiro, as quais se explicitam no narrador, são sempre aptas a dar conselhos. E conselho aqui não é uma mera transmissão de informações, mas é prioritariamente uma ação própria do sábio ${ }^{49}$, nutrida na memória. Apesar de parecer antiquado para nossos moldes contemporâneos, o que é causado exatamente pela incomunicabilidade das experiências, o conselho aponta características essenciais do narrador e da narrativa, como o senso prático presente nele e a dimensão utilitarista dela. Isto porque o narrador apega-se à experiência e a difunde, valorizando uma dimensão que foi deixada de lado no nosso tempo (marcado pelo desenvolvimento das forças produtivas): o valor da tradição oral. O narrador é a figura na qual

\footnotetext{
${ }^{44}$ Walter Benjamin. Experiência e pobreza. Op. Cit. p. 119.

${ }^{45}$ Walter Benjamin. "Parque Central" in: Obras Escolhidas III (Trad. José Carlos Martins Barbosa e Hemerson Alves Baptista), São Paulo: Brasiliense, 1989. p. 172.

46 "Ficamos pobres. Abandonamos uma depois da outra todas as peças do patrimônio humano, tivemos que empenhá-las muitas vezes a um centésimo do seu valor para recebermos em troca a moeda miúda do "atual" Walter Benjamin. Experiência e pobreza. Op. Cit. p. 119).

${ }^{47}$ A categoria de inconsciente coletivo pode ser buscada a partir da compreensão exposta por Jung, no âmbito da psicologia. Maiores esclarecimentos em Carl Gustav Jung. Obras Completas. Petrópolis: Vozes, 1966; Carl Gustav Jung. O Homem e Seus Símbolos. Rio de Janeiro: Nova Fronteira, 1964. Carl Gustav Jung. Memórias Sonhos e Reflexões. Rio de Janeiro: Nova Fronteira, 1961.

${ }^{48}$ Walter Benjamin. "O Narrador: considerações sobre a obra de Nikolai Leskov" in: Walter Benjamin. Magia e técnica, arte e política: ensaios sobre a literatura e história da cultura. São Paulo: Brasiliense, 1994, p. 198.

49 "O conselho tecido na substância viva da existência tem um nome: sabedoria" Walter Benjamin. O Narrador. Idem.. p. 200).
} 
"o justo se encontra consigo mesmo" "50 porque ele que exercita a virtude de buscar a verdade da tradição, conhece o valor da memória (Eingedenken): "a mais épica de todas as faculdades" 51 e com o resgate que empreende dos tesouros da tradição recolhidos meio aos escombros do esquecimento, ele compreende que "a sabedoria é o lado épico da verdade." 52 Mas o narrador também compreende que não é mais possível recolher os bens dispersos pela história, em sua totalidade, sem uma sentimento de extrema melancolia, traduzida na obra de Baudelaire por Spleen. O poeta vê nele a matéria prima de sua poesia. Com melancolia ela perde o halo de genialidade. Resta ao gênio do poeta vender sua poesia e seu trabalho como simples mercadoria, igualada a qualquer outro produto saído da fábrica. O sentimento de desolação diante dos acontecimentos do mundo levam o poeta-narrador a compreender que "o tédio é o pássaro de sonho que choca os ovos da experiência". 53

Um sinal de que a tradição oral tem sido posta em xeque na nossa época é a invenção do romance. Ele, estritamente ligado ao lucro proporcionado pela imprensa, mostra o romancista como um indivíduo isolado, só, e, por esse motivo, longe da experiência, da sabedoria e do conselho, o que faz surgir uma nova forma de comunicação: a informação.

Há, entretanto, uma diferença estupenda entre o saber - próprio da obra do narrador - e a informação. Enquanto o primeiro se liga ao material da arte de narrar, ou seja, à experiência, a informação, presa a um instante passageiro e fugaz, busca explicações precisas e imediatas, que, no entanto, se perdem com a chegada de uma outra informação que a substitui. Sua vida é efêmera. Por esse motivo, "cada manhã recebemos notícias de todo o mundo. E, no entanto, somos pobres em histórias surpreendentes"

Nossa época parece ter deixado de lado o "dom de ouvir" e de contar histórias, o que dá à narrativa a impossibilidade de resistir. Ela, como forma artesanal de comunicação ${ }^{55}$, está paulatinamente sendo substituída pela rapidez instantânea da informação. E isso se explica pela impaciência do homem de hoje: "[...] [ele] não cultiva o que não pode ser abreviado",56, e por isso tenta abreviar até a narrativa, criando a short story emancipada da tradição oral.

Até aqui o conceito de experiência está como que subjacente a toda discussão. Mas experiência, em Benjamin, acena para a questão da autoridade. Esta, entendida como adveniente dos anos de vivência - e por isso ligada à velhice rica de experiências -, se faz notar sobretudo no momento da morte. Isto se explica e se evidencia com mais clareza quando da percepção de que a morte é ocasião oportuna para o exercício desta autoridade, já que nesse momento há a viabilização excelente da transmissibilidade da sabedoria do homem e sua existência vivida ${ }^{57}$. Por isso mesmo é que esta aparece no texto identificada com a expressão "espetáculo da morte", que cada vez mais tem se distanciado do mundo dos vivos como que num jogo de palavras que retoma a ideia da desvinculação entre experiência e nosso tempo. E pior: se "a morte é a sanção de tudo o que o narrador pode contar, é da morte que ele deriva sua autoridade" ${ }^{, 58}$ o que mais uma vez garante a força do argumento benjaminiano de que realmente há um declínio perceptível da arte de narrar.

Nesse sentido o que se pode notar da narrativa é que ela não se perde com a sucessão de informações renovadas, pois sua existência se funda na experiência existencial mesma dos indivíduos. E se assim o é, a narrativa parece ter muito a ver com o trabalho do cronista, que é

\footnotetext{
${ }^{50}$ Walter Benjamin. O Narrador, Idem. p. 221.

${ }^{51}$ Walter Benjamin. O Narrador. Idem, p. 210.

${ }^{52}$ Walter Benjamin. O Narrador. Idem. p. 201.

${ }^{53}$ Walter Benjamin. O Narrador. Idem. p. 204

${ }^{54}$ Walter Benjamin. O Narrador. Idem. p. 203.

55 "Ela [a narrativa] mergulha a coisa na vida do narrador para em seguida retirá-la dele" (Walter Benjamin. $O$ Narrador... Op. Cit. p. 205).

${ }^{56}$ Walter Benjamin. O Narrador... Idem. p. 206

${ }^{57}$ Walter Benjamin. O Narrador... Idem. p. 207.

${ }^{58}$ Walter Benjamin. O Narrador... Idem. p. 208.
} 
como que o narrador da história, este vinculado à história profana e aquele ligado à história sagrada.

Outro aspecto interessante da narrativa em Benjamin é que ela resguarda uma relação sui generis entre aquele que narra e aquele que o ouve, o que se revela no desejo de se conservar o conteúdo da narração por parte do ouvinte, para que lhe seja possível reproduzir o que guardou, ressaltando-se, assim, a importância da dimensão da memória no contexto geral da narrativa. Mas não uma memória qualquer, senão uma reminiscência que "[...] funda a cadeia da tradição, que transmite acontecimentos de geração em geração" "59. A dimensão da tradição é ressaltada e defendida, pois é dela que advém a autoridade e a experiência. Mas aqui aparece a necessidade de se apresentar a diferença, mais uma vez, da narrativa em face ao romance: ela conta com a breve memória do narrador, ele com a memória perturbadora do romancista $^{60}$. Isso explica a ideia de finalização do romance, que não aparece na narrativa. Melhor:

[...] numa narrativa a pergunta - e o que aconteceu depois? - é plenamente justificada. $\mathrm{O}$ romance, ao contrário, não pode dar um único passo além daquele limite em que, escrevendo na parte inferior da página a palavra fim, convida o leitor a refletir sobre o sentido de uma vida ${ }^{61}$.

O leitor de um romance é sempre como o seu compositor: solitário, isolado. Quem lê a narrativa ou mesmo a escuta, ao invés, se acompanha do narrador, que sempre tem suas raízes no povo, sobretudo nas camadas mais artesanais. E mais: há uma facilidade enorme de mobilidade do narrador nos degraus da experiência, o que lhe faz ultrapassar os limites da morte, já que a experiência que se privilegia aqui tem um quê de coletividade. E uma das mais belas e atraentes formas de enxergá-lo está no conto de fadas que, ao se opor às meticulosidades engenhosas do pensamento mítico, “[...] sabia dar um bom conselho, quando ele era difícil de obter, e oferecer sua ajuda, em caso de emergência" ${ }^{2}$.

A relação entre o narrador e sua matéria-prima é fundamentalmente artesanal. E ele se situa, pela autoridade de quem se impregnou de experiências durante a vida, entre os grandes mestres e sábios, podendo legar aos homens os melhores conselhos ${ }^{63}$.

Nosso tempo, porém, é desmemoriado e cumpre resgatar a dimensão da Eingedenken (reminiscência). Benjamin mostra que o conselho é sabedoria autêntica e se inclui necessariamente nos conceitos de experiência e memória. $\mathrm{O}$ conselho tem valor e se apresenta como sabedoria exatamente porque se fundamenta na autoridade de quem possui experiência.

\footnotetext{
${ }^{59}$ Walter Benjamin. O Narrador... Op. Cit. p. 211.

60 "[...] a rememoração, musa do romance, surge ao lado da memória, musa da narrativa, depois que a desagregação da poesia épica apagou a unidade de sua origem comum na reminiscência" (BENJAMIN, W. $O$ Narrador... Op. Cit. p. 211).

${ }^{61}$ Walter Benjamin. O Narrador... Op. Cit. p. 213.

${ }^{62}$ Walter Benjamin. O Narrador... Op. Cit. p. 215.

63 "Podemos ir mais longe e perguntar se a relação entre o narrador e sua matéria - a vida humana - não seria ela própria uma relação artesanal. Não seria sua tarefa trabalhar a matéria-prima da experiência - a sua e a dos outros - transformando-a num produto sólido, útil e único? Talvez se tenha uma noção mais clara desse processo através do provérbio, concebido como uma espécie de ideograma de uma narrativa. Podemos dizer que os provérbios são ruínas de antigas narrativas, nas quais a moral da história abraça um acontecimento, como a hera abraça um muro.

Assim definido, o narrador figura entre os mestres e os sábios. Ele sabe dar conselhos: não para alguns casos, como o provérbio, mas para muitos casos, como o sábio. PIS pode recorrer ao acervo de toda uma vida (uma vida que não inclui apenas a própria experiência, mas em grande parte a experiência alheia. $\mathrm{O}$ narrador assimila à sua substância mais íntima aquilo que sabe por ouvir dizer). Seu dom é poder contar sua vida; sua dignidade é contá-la inteira. O narrador é o homem que poderia deixar a luz tênue de sua narração consumir completamente a mecha de sua vida. Daí a atmosfera incomparável que circunda o narrador [...]. O narrador é a figura na qual o justo se encontra consigo mesmo" ( Walter Benjamin. O Narrador... Op. Cit. p. 221).
} 
E se hoje há repúdio ao conselho, nosso autor salienta a importância de se salvar este fragmento da tradição, andando na contramão dos apelos de um tecnicismo exacerbado contemporâneo que nada mais faz que iludir os indivíduos, que dele se tornam meros fantoches:

Conhecemos a história de um autômato construído de tal modo que podia responder a cada lance de um jogador de xadrez com um contralance, que lhe assegurava a vitória. Um fantoche vestido à turca, com um narguilé na boca, sentava-se diante do tabuleiro, colocado numa grande mesa. Um sistema de espelhos criava a ilusão de que a mesa era totalmente visível, em todos os seus pormenores. Na realidade, um anão corcunda se escondia nela, um mestre no xadrez, que dirigia com cordeis a mão do fantoche. Podemos imaginar uma contrapartida filosófica desse mecanismo. O fantoche chamado "materialismo histórico" ganhará sempre. Ele pode enfrentar qualquer desafio, desde que tome a seu serviço a teologia. Hoje, ela é reconhecidamente pequena e feia e não ousa mostrar-se $\mathrm{s}^{64}$.

A salvação é apresentada por Benjamin como tarefa urgente. E, a exemplo do conceito teológico do agora da salvação ${ }^{65}$, o autor expõe a necessidade de uma soteriologia presente, no agora da ação político-transformadora do indivíduo, que se dá através da dimensão do conhecimento (Jetzt der Erkennbarkeit ${ }^{66}$ ). Tal como o conhecimento espinosano, responsável pelo desenvolvimento da potência do homem e seu conatus, essa força se mantém atuante. Desmistificando a história de opressões e catástrofes, o novo conceito de história, sustentado em uma historiografia inconsciente - e por isso capaz de ajustar as contas com o historicismo - é possível pela energia libertária da frágil força messiânica. Ela é capaz de convocar a sabedoria andando na contramão do pensamento lógico e analítico, para construir uma ação política transformadora do homem: a educação que advém do poder divino sobre a existência aparece como política de resistência e referência de salvação, ${ }^{67}$.

\section{REFERÊNCIAS}

BENJAMIN, W. "A obra de arte na era de sua reprodutibilidade técnica". in: Magia e técnica, arte e política: ensaios sobre a literatura e a história da cultura. São Paulo: Brasiliense, 1994.

"Experiência e pobreza". in: BENJAMIN, W. Magia e técnica, arte e política: ensaios sobre a literatura e a história da cultura. São Paulo: Brasiliense, 1994.

"O Narrador: considerações sobre a obra de Nikolai Leskov" in: BENJAMIN, W. Magia e técnica, arte e política: ensaios sobre a literatura e história da cultura. São Paulo: Brasiliense, 1994. . Origem do drama barroco alemão. São Paulo: Brasiliense, 1984.

\footnotetext{
${ }^{64}$ Walter Benjamin. Sobre o conceito de história. Op. cit., p. 222.

${ }^{65}$ Para a teologia cristã, é importante considerar a escatologia compreendida a partir de uma tensão constante entre o já e o ainda não. Nesse sentido, o Evangelho de Lucas apresenta a discussão sobre esta tensão, como representante maior no contexto do Novo Testamento.

${ }^{66} \mathrm{O}$ patrimônio cultural, o qual Benjamin lamenta não ser utilizado pela experiência, é revitalizado nesse agora do cognoscível, que deve fundar, pela experiência, o agora da salvação (Jetztzeit). Walter Benjamin. "Parque Central" in: Obras escolhidas III - Charles Baudelaire - um lírico no auge do capitalismo, Opus cit. p. 173

${ }^{67}$ Tal como o conhecimento espinosano é responsável pelo desenvolvimento da potência do indivíduo e seu conatus.
} 
"Sobre o conceito de história". In: BENJAMIN, W. Magia e técnica, arte e política: ensaios sobre a literatura e a história da cultura. São Paulo: Brasiliense, 1994.

"Teorias do fascismo alemão". In: BENJAMIN, W. Magia e técnica, arte e política: ensaios sobre a literatura e a história da cultura. São Paulo: Brasiliense, 1994.

CALLADO. Tereza de Castro. Walter Benjamin - A Experiência da Origem. Fortaleza: Eduece, 2006.

CALLADO. Tereza de Castro. "O comportamento ex-offico do estadista na teoria da soberania em Origem do Drama Barroco Alemão" in: Ética e Metafísica, Fortaleza: Eduece, 2007, pp.111-142.

CALLADO. Tereza de Castro. A teoria da melancolia em Walter Benjamin: a versão do taedium vitae medieval e de seus elementos teológicos na concepção de melancolia do barroco no site: http://gewebe.com.br/cadernos.htm in: Cadernos Walter Benjamin $\mathrm{N}^{\mathrm{o}} 1$ Julho-Dezembro 2008.

CALLADO. Tereza de Castro. "As metamorfoses da consciência burguesa e a imagem dialética" no site: http://www.gewebe.com.br/cadernos.htm in: Cadernos Walter Benjamin $\mathrm{N}^{\circ}$ 4, Janeiro-Junho 2010.

CALLADO. Tereza de Castro. "O drama da alegoria no século XVII barroco" in: Kalagatos Revista de Filosofia, Fortaleza: Eduece, 2004.

CALLADO. Tereza de Castro. A metafísica benjaminiana, a mercadoria e o agora (Jetztzeit) no site: http://www.gewebe.com.br/cadernos.htm in: Cadernos Walter Benjamin $\mathrm{N}^{\circ} 2$, Janeiro-Junho 2009.

JUNG, C. G. Obras Completas. Petrópolis: Vozes, 1966.

JUNG, C. G. O Homem e Seus Símbolos. Rio de Janeiro: Nova Fronteira, 1964.

JUNG, C. G. Memórias Sonhos e Reflexões. Rio de Janeiro: Nova Fronteira, 1961.

LARROSA, J. Notas sobre a experiência e o saber de experiência. Palestra proferida no $13^{\circ}$ COLE-Congresso de Leitura do Brasil, Unicamp, Campinas/SP, julho de 2001. <http:// www.miniweb.com.br/Atualidade/INFO/textos/saber.htm>. Acesso em junho de 2005. In: BESSA, B. S. As experiências de Walter Benjamin. Morpheus - Revista Eletrônica em Ciências Humanas - Ano 05, número 09, 2006 - ISSN 1676-2924. Disponível em http://www.unirio.br/morpheusonline/numero09-2006/bessa.htm\#_edn1. Acesso em 12 de março de 2010. 